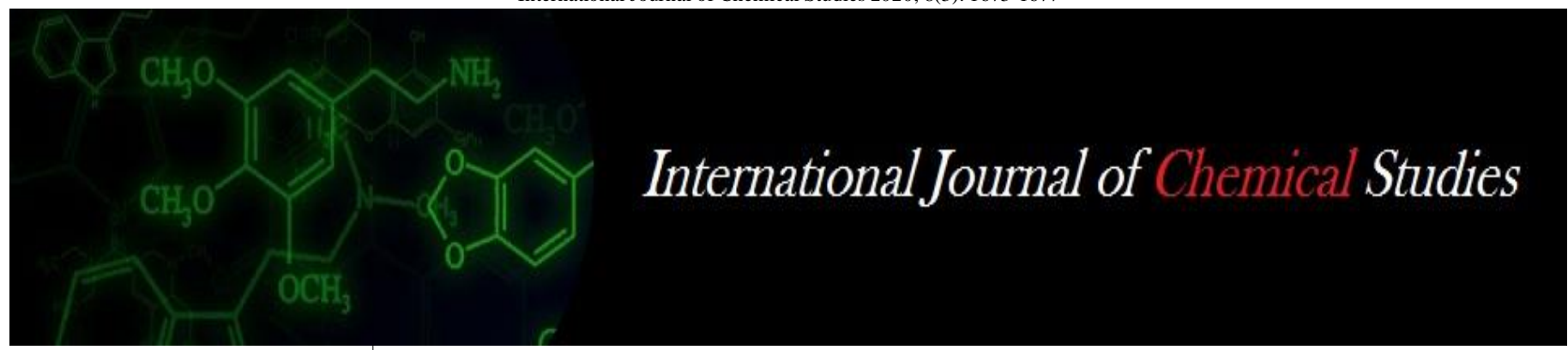

P-ISSN: 2349-8528

E-ISSN: 2321-4902

www.chemijournal.com

IJCS 2020; 8(3): 1673-1677

(C) 2020 IJCS

Received: 14-03-2020

Accepted: 16-04-2020

\section{Kiran Rathore}

Department of Soil Science \&

Agricultural Chemistry College of

Agriculture, Raipur,

Chhattisgarh, India

\section{Alok Tiwari}

Department of Soil Science \&

Agricultural Chemistry College of

Agriculture, Raipur,

Chhattisgarh, India

\section{Rahul Kumar}

College of Agriculture,

Bharatpur, Rajasthan, India
Corresponding Author: Kiran Rathore

Department of Soil Science \& Agricultural Chemistry College of Agriculture, Raipur,

Chhattisgarh, India

\section{Long term effect of inorganic fertilizers and organic manures on soil fertility status, microbial biomass carbon, and yield of rice on inceptisol}

\author{
Kiran Rathore, Alok Tiwari and Rahul Kumar
}

DOI: https://doi.org/10.22271/chemi.2020.v8.i3w.9440

\begin{abstract}
The experiment was conducted during the kharif season at research farm, Indira Gandhi Krishi Viswavidyalaya, Raipur to investigate the long term effect of Inorganic fertilizer and organic manures on soil fertility, microbial biomass carbon and yield or rice. The soil was sandy loan and locally known as matasi, neutral in $\mathrm{pH}$, Low in nitrogen, medium in $\mathrm{P}$ and $\mathrm{K}$. the experiment was laid in $\mathrm{RBD}$ and replicated three times with eleven treatment $\mathrm{T}_{1}-$ No Fertilizer, No Organic manure (Control), $\mathrm{T}_{2}-50 \%$ Recommended NPK (40:30:20), $\mathrm{T}_{3}-75 \%$ Recommended NPK,T4-100\% Recommended NPK (80:60:40), $\mathrm{T}_{5}-50 \%$ Recommended NPK $+50 \% \mathrm{~N}$ through Farm yard manure, $\mathrm{T}_{6}-75 \%$ Recommended $\mathrm{NPK}+25 \% \mathrm{~N}$ through Farm yard manure, $\mathrm{T}_{7}-50 \%$ Recommended $\mathrm{NPK}+50 \% \mathrm{~N}$ through rice residue, $\mathrm{T}_{8-}$ $75 \%$ Recommended NPK $+25 \% \mathrm{~N}$ through rice residue, $\mathrm{T}_{9}-50 \%$ Recommended NPK $+50 \% \mathrm{~N}$ through Green manure, $\mathrm{T}_{10-}-75 \%$ Recommended NPK $+25 \% \mathrm{~N}$ through Green manure, $\mathrm{T}_{11}$ - Conventional Farmer' Practice (50:30:20). A medium duration high yielding rice variety Mahamaya was taken as test crop. The results revealed that combination application of inorganic fertilizer and organic manure i.e. integrated of fertilizer and manure improve chemical propertied of soil like organic carbon, available $\mathrm{N}, \mathrm{P}$, and $\mathrm{K}$ status in soil microbial biomass in soil as compare to absolute and alone inorganic fertilizer. Application of organic (FYM, Rice residue, Green manure) with inorganic fertilizer in rice along with 50 and $75 \%$ RDF gave higher soil organic carbon available $\mathrm{P}$ and MBC content of soil as compared to control. The result revealed that $\mathrm{MBC}$ positively significant correlated with organic carbon, available $\mathrm{N}, \mathrm{P}$ and $\mathrm{K}$ and yield of rice.
\end{abstract}

Keywords: Rice, microbial biomass carbon, organic and inorganic fertilizer

\section{Introduction}

Rice is an important crop grown in nearly 44 million ha of land in the country with the productivity of $2.2 \mathrm{t} / \mathrm{ha}$ which is less than the productivity of many Asian countries. In Chhattisgarh, rice occupies average of 3.6 million ha with the productivity of the state ranging between 1.2 to 1.6 t/ha depending upon the rainfall. Chhattisgarh state occupies 13.51 million hectares with a gross cropped area of about 5.68 million ha. The geographical area of the state is situated between $17^{0} 46^{\prime}$ to $24^{\circ} 6^{\prime} \mathrm{N}$ latitude and $80^{\circ} 15^{\prime}$ to $84^{\circ} 51^{\prime}$ E longitude. Inceptisol are shallow, well-drained, loamy soils on the gentle sloping and undulating plateau (slightly dissected) with moderate erosion and occurrence of stones. They are classified as loamy, kaolinitic, isohyperthermic, Lithic Ustropepts. Inceptisol are locally called matasi soil. They have a light texture and a shallow to moderate depth.

Soil organic matter is thus an important component of soil quality and productivity. Nevertheless, its measurement alone does not adequately reflect changes in soil quality and nutrient status (Mathers et al., 2000; Chen et al., 2004) ${ }^{[13,4]}$. Measurements of biologically active fractions of organic matter, such as microbial biomass carbon (MBC) and nitrogen $(\mathrm{MBN})$, and potential $\mathrm{C}$ and $\mathrm{N}$ mineralization better reflects changes in soil quality and productivity that alter nutrient dynamics (Hole et al., 2005) ${ }^{[10]}$. Because it is living, the microbial biomass responds much more quickly to changing soil conditions, particularly decrease or increase in plant or animal residues, than does soil organic matter as a whole. Measurable changes in microbial biomass would thus reflect changes in soil fertility due, for example, to changes in the total pool of soil organic matter (El-Ghamry et al., 2001) ${ }^{[5] .}$ 
The soil microbial biomass (MBC and $\mathrm{MBN}$ ) is the active component of the soil organic pool playing an important role in nutrient cycling and plant nutrition and functioning of different ecosystems.

It is responsible for organic matter decomposition thus affecting soil nutrient content and, consequently, primary productivity in most biogeochemical processes in terrestrial ecosystems (Gregorich et al., 2000; Haney et al., 2001) ${ }^{[7,9]}$. Applying organic amendments to soil not only increases the total organic carbon content and its different fractions but also has a series of effects on microbial proliferation and activity (Tejada et al., 2006; Ros et al., 2003) ${ }^{[27,18]}$. Soil microbial biomass is undoubtedly a valuable tool for understanding and predicting changes in soil fertility management and associated soil conditions such as nutrient dynamics and soil reaction (Sharma et al., 2004; Yougun et al., 2007) ${ }^{[21,32]}$. It has assumed greater significance and increasing interest in its determination (Azam et al., 2003) ${ }^{[2]}$.

Soil microbial diversity is one of the most important microbial parameters in soil. It has been demonstrated that soil microbial diversity is affected by anthropogenic disturbance (Fox and MacDonald, 2003) [6]. Inorganic fertilizers, especially nitrogen $(\mathrm{N})$, phosphorus $(\mathrm{P})$ and potassium $(\mathrm{K})$, not only serve to maintain or improve crop yields, but their application also directly or indirectly induce changes in soil chemical, physical and biological properties. Some studies showed that chemical fertilizers increase biomass C and N, Sarathchandra et al. (2001) ${ }^{[19]}$ reported that nitrogen and phosphate fertilizers had no significant effects on soil microbial populations and $\mathrm{N}$ application reduced the functional microbial diversity in pasture soils.

"Long term effect of inorganic fertilizers and organic manures on soil fertility status, microbial biomass carbon, and yield of rice on inceptisol" was undertaken with the objectives effect of integrated nutrient management practices on soil microbial biomass carbon and effect of combination of inorganic and organic treatment on growth and yield of rice crop.

\section{Method and Materials}

The field experiment was conducted at the research farm, Indira Gandhi Krishi Vishwavidyalaya, Raipur (Chhattisgarh) during kharif. Raipur comes under agro-climatic plain Zone of Chhattisgarh State and lie at $21^{\circ} 16^{\prime} \mathrm{N}$ latitude and $81^{\circ} 26^{\prime}$ East longitude with an altitude of $289.56 \mathrm{~m}$ above the mean sea level. The experiment were laid out in eleven treatment combinations. $\mathrm{T}_{1}$-No Fertilizer, No Organic manure (Control), $\mathrm{T}_{2}-50 \%$ Recommended NPK (40:30:20), $\mathrm{T}_{3}-75 \%$ Recommended NPK, $\mathrm{T}_{4}-100 \%$ Recommended NPK (80:60:40), $\mathrm{T}_{5}-50 \%$ Recommended $\mathrm{NPK}+50 \% \mathrm{~N}$ through Farm yard manure, $\mathrm{T}_{6}-75 \%$ Recommended NPK $+25 \% \mathrm{~N}$ through Farm yard manure, $\mathrm{T}_{7}-50 \%$ Recommended NPK $+50 \% \mathrm{~N}$ through rice residue, $\mathrm{T}_{8}-75 \%$ Recommended NPK $+25 \% \mathrm{~N}$ through rice residue, $\mathrm{T}_{9}-50 \%$ Recommended NPK $+50 \% \mathrm{~N}$ through Green manure, $\mathrm{T}_{10}-75 \%$ Recommended NPK $+25 \% \mathrm{~N}$ through Green manure, $\mathrm{T}_{11}$ - Conventional Farmer' Practice (50:30:20). A medium duration high yielding rice variety Mahamaya was taken as test crop with three replications. $\mathrm{pH}$ measured by glass electrode in 1:2.5 soil water as described by Piper (1967) ${ }^{[17]}$. The conductivity of supernatant liquid was determined by Solubridge as described by Black (1965) ${ }^{[3]}$. Organic carbon by Walkley and Black's (1934) ${ }^{[31]}$ rapid titration method as described by Jackson (1967) ${ }^{[8]}$. Available nitrogen content in soil was determined by alkaline potassium permanganate method as described by
Subbiah and Asija (1956) ${ }^{[25]}$. Available phosphorus was estimated by the ascorbic acid method as described by Olsen, (1954) ${ }^{[16]}$. Absorbance readings were taken at an $882 \mathrm{~nm}$ wavelength using a double beam spectrophotometer. Available potassium was extractant neutral normal ammonium acetate by using flame photometer. It was described by Jackson in $1967^{[8]}$. Microbial biomass carbon is determined by the modified fumigation -incubation method (Vance et al 1987) ${ }^{[29]}$ in which the main aim was to see if the amounts of $\mathrm{C}$ which could be directly extracted from soils following fumigation were related to microbial biomass $\mathrm{C}$. In this method, $40-45 \mathrm{gm}$ soil was weighed in to a $500 \mathrm{ml}$ reagent bottle and kept for fumigation. Ethanol- free chloroform was prepared immediately before fumigation. The chloroform was poured in a separating funnel and washed with concentrated $\mathrm{H}_{2} \mathrm{SO}_{4}$ (each with half the volume of chloroform) and another three times with the same volume of distilled water similarly and the bottom whitish phase was collected. All the washing was given to make the chloroform free of ethanol. The required volume of ethanol free chloroform $(10-20 \mathrm{ml})$ was kept in $500 \mathrm{ml}$ reagent bottle containing soil and placed in dark for 24 hrs. After 24 hours, the lid of the bottle is opened for $1 / 2$ hours so that gasses pass out.

\section{Results and Discussion \\ Effect of long term inorganic fertilizer and organic manure application on soil chemical properties \\ Soil pH}

Soil $\mathrm{pH}$ was determined in different treatments after the harvest of rice crop and the data was presented in Table 1. The soil $\mathrm{pH}$ after the harvest of rice crop showed nonsignificant difference with respect to different organic manures and inorganic fertilizers applied. In all the treatments, there was no remarkable change in soil $\mathrm{pH}$ as compared to the control. However, higher value (7.5) of $\mathrm{pH}$ was recorded in $75 \% \mathrm{RDF}$ treatment and lower value (7.1) of $\mathrm{pH}$ recorded in $75 \% \mathrm{RDF}+25 \%$ GM-N. Similar finding had been recorded by Sime (2001) ${ }^{[23]}$. Buffering action of soils does not permit to alter the soil $\mathrm{pH}$. The rise in $\mathrm{pH}$ is ascribed to decrease in organic carbon concentration of the soil due to continuous cropping as reported by Agarwal et al (2010) [1] and Swarup and Yaduvashi (2000) ${ }^{[26]}$ also reported that soil $\mathrm{pH}$ was higher in inorganic fertilizer treatment plot as compared to NPK + green manure treatment plots.

\section{Soil EC}

The data on electrical conductivity (EC) was presented in Table 1 revealed that the effect of applied organic and inorganic fertilizer on EC was statistically non significant. However, higher value $\left(0.25 \mathrm{dSm}^{-1}\right)$ of $\mathrm{EC}$ was recorded in $75 \% \mathrm{RDF}+25 \%$ FYM-N treatment and lower value $\left(0.20 \mathrm{dSm}^{-1}\right)$ of EC recorded in Farmer's practice treatment. Soil $\mathrm{pH}$ showed non-significant change over initial value with the applied organic manure and inorganic fertilizer treatment. The different treatment did not influence the $\mathrm{pH}$ and EC of soil. The values were almost constant and similar finding was also reported by Urkurkar et al. (2010) ${ }^{[30]}$, with almost same set of treatment in rice crop.

\section{Organic carbon}

The data on soil organic carbon (SOC) after harvest of rice crop was presented in Table 1 . The SOC ranges vary from 0.56 to $0.75 \mathrm{gm} \mathrm{kg}^{-1}$ amongst different treatments. The level of application of inorganic fertilizer along with organic manure significantly increased the organic carbon. After harvest of 
rice, SOC was recorded highest $\left(7.5 \mathrm{gm} \mathrm{kg}^{-1}\right)$ in $50 \% \mathrm{RDF}+$ $50 \%$ FYM-N, followed by $50 \%$ RDF $+50 \%$ GM-N while, lowest $\left(5.6 \mathrm{gm} \mathrm{kg}^{-1}\right)$ under control plots. The same finding during experimentation revealed that integrated use of inorganic fertilizer with organic manures increased the organic carbon and N, P and K status of the soil as reported by Sharma et al. (2009) ${ }^{[22]}$.

Table 1: Effect of long term fertilizer and manure application on soil $\mathrm{pH}, \mathrm{EC}$ and organic carbon after harvest of rice

\begin{tabular}{|c|c|c|c|c|}
\hline \multirow{2}{*}{ Treatments } & \multicolumn{3}{|c|}{ After harvest of rice } \\
\cline { 3 - 5 } & pH & $\mathbf{E C}\left(\mathbf{d S m}^{-1}\right)$ & $\begin{array}{c}\text { Organic carbon } \\
\left(\mathbf{g m ~ k g}^{-1}\right)\end{array}$ \\
\hline T1 & Control & 7.3 & 0.22 & $5.6 \mathrm{e}$ \\
\hline T2 & $50 \%$ RDF (40:30:20) & 7.3 & 0.22 & $6.2 \mathrm{~d}$ \\
\hline T3 & 75\% RDF & 7.5 & 0.23 & $6.4 \mathrm{~d}$ \\
\hline T4 & 100\% RDF (80:60:40) & 7.4 & 0.21 & $7.2 \mathrm{~b}$ \\
\hline T5 & $50 \%$ RDF+50\% FYM-N & 7.2 & 0.22 & $7.5 \mathrm{a}$ \\
\hline T6 & 75\%RDF+25\% FYM-N & 7.3 & 0.25 & $6.8 \mathrm{c}$ \\
\hline T7 & 50\%RDF+50\% RR-N & 7.2 & 0.21 & $6.8 \mathrm{c}$ \\
\hline T8 & $75 \%$ RDF+25\% RR-N & 7.2 & 0.23 & $6.7 \mathrm{c}$ \\
\hline T9 & 50\% RDF+50\% GM-N & 7.2 & 0.22 & $7.2 \mathrm{~b}$ \\
\hline T10 & $75 \%$ RDF+25\% GM-N & 7.1 & 0.22 & $6.8 \mathrm{c}$ \\
\hline T11 & Farmer practices (50:30:20) & 7.3 & 0.2 & $6.6 \mathrm{c}$ \\
\hline & SEm+ & 0.08 & 0.01 & 0.09 \\
\hline & CD (P=0.05) & NS & NS & 0.27 \\
\hline
\end{tabular}

FYM- farm yard manure, RR- rice residues, GM- green manure

\section{Available N}

The data on available $\mathrm{N}$ content in soil after harvest of rice crop was tabulated in Table 2 . The available $\mathrm{N}$ varies between 160 to $272 \mathrm{~kg} / \mathrm{ha}$ amongst different treatments. Application of fertilizer along with FYM and GM significantly increase the available $\mathrm{N}$ in soil over $100 \% \mathrm{RDF}$ alone treatment. Higher amount of available $\mathrm{N}\left(272 \mathrm{~kg} \mathrm{ha}^{-1}\right)$ in soil was noted in $50 \%$ $\mathrm{RDF}+50 \% \mathrm{GM}-\mathrm{N}$ followed by $50 \% \mathrm{RDF}+50 \% \mathrm{FYM}-\mathrm{N}$ and rice residues and lowest $\left(160 \mathrm{~kg} \mathrm{ha}^{-1}\right)$ was recorded in control. Adding green manure favored the soil conditions and might have helped in the mineralization of soil $\mathrm{N}$ leading to build up of increased available $\mathrm{N}$.

\section{Available P}

The data on available $\mathrm{P}$ content in soil after harvest of rice crop was arranged in Table 2 . The range of available $P$ was vary from 8.68 to $31.37 \mathrm{~kg} / \mathrm{ha}$ in various treatments. Available $\mathrm{P}$ content of soil was increased as compared to its initial status. Highest available P $\left(31.37 \mathrm{~kg} \mathrm{ha}^{-1}\right)$ was obtained with $50 \%$ RDF + 50\% FYM-N followed by $\left(28.88 \mathrm{~kg} \mathrm{ha}^{-1}\right) 50 \%$ $\mathrm{RDF}+50 \%$ GM-N treatment and lowest $\left(20.55 \mathrm{kgha}^{-1}\right)$ in $50 \%$ RDF treated plot except control. When RR was incorporated in the soil, the $\mathrm{P}$ availability increases, but the response was not significant when compared with $50 \%$ as well as $75 \%$ RDF i.e. absolute inorganic fertilizer application. Continuous use of balanced fertilizer since 1991-92 is conducive for maintaining the soil available $\mathrm{P}$. The results of the present study also revealed that higher available $\mathrm{P}$ content were recorded in integrated nutrient management treatments as compared to absolute control. It was also observed that successive significant increase had occurred due to increasing levels of fertilizer application along with organic manure addition in soil. Similar results have also been reported by Thakur et al., (2010) ${ }^{[28]}$. They found that exclusion and/or omission of P in the fertilizer schedule had resulted in lowering the available $\mathrm{P}$ content in the soil. The results also support that increasing levels of fertilizer application had resulted in substantially enhancing the available $\mathrm{P}$ content and so was the case with use of FYM along with balanced dose of fertilizer. Swarup and Yaduvanshi (2000) ${ }^{[26]}$, Thakur et al., (2010) ${ }^{[28]}$ have also reported the beneficial effects of organic matter on available $\mathrm{P}$ in soils.

\section{Available K}

The data on available $\mathrm{K}$ after harvest of rice crop was presented in Table 2.Available K ranged between from 207 to $264 \mathrm{~kg} / \mathrm{ha}$ amongst various combination of inorganic and organic nutrient management treatment. The higher available $\mathrm{K}\left(264 \mathrm{~kg} \mathrm{ha}^{-1}\right)$ was obtained with $50 \% \mathrm{RDF}+50 \%$ FYM-N and lower $\left(207 \mathrm{~kg} \mathrm{ha}^{-1}\right)$ in control. Application of FYM along with 50\% RDF inorganic fertilizer results significantly higher amount of available N, P and K in soil as compared to $100 \%$ RDF fertilizer alone. Continuous use of N,P and $\mathrm{K}$ fertilizer over the years reduced the organic carbon status leading to a decline in the availability of macronutrients in soil whereas, FYM incorporation along with N,P and $\mathrm{K}$ fertilizers increased the organic $\mathrm{C}$ status of soil which consequently caused higher availability of N,P and $\mathrm{K}$ in soil. These findings are in agreement with those of Krishna (2003) ${ }^{[12]}$.

Table 2: Effect of continuous application of fertilizer and manure on available $\mathrm{N}, \mathrm{P}$ and $\mathrm{K}$ content in soil after harvest of rice

\begin{tabular}{|c|c|c|c|c|}
\hline \multirow{2}{*}{ Treatments } & \multicolumn{4}{|c|}{ Available nutrients $\left(\right.$ kg ha $\left.^{-1}\right)$} \\
\cline { 3 - 5 } & & N & P & K \\
\hline T1 & Control & $160 \mathrm{~h}$ & $8.68 \mathrm{c}$ & $207 \mathrm{f}$ \\
\hline T2 & $50 \%$ RDF $(40: 30: 20)$ & $207 \mathrm{~g}$ & $20.55 \mathrm{bc}$ & $225 \mathrm{e}$ \\
\hline T3 & $75 \%$ RDF & $238 \mathrm{e}$ & $22.81 \mathrm{~b}$ & $229 \mathrm{e}$ \\
\hline T4 & $100 \%$ RDF (80:60:40) & $256 \mathrm{~d}$ & $27.87 \mathrm{a}$ & $260 \mathrm{a}$ \\
\hline T5 & $50 \%$ RDF+50\% FYM-N & $268 \mathrm{ab}$ & $31.37 \mathrm{a}$ & $264 \mathrm{a}$ \\
\hline T6 & $75 \%$ RDF+25\% FYM-N & $263 \mathrm{bc}$ & $27.58 \mathrm{a}$ & $247 \mathrm{bc}$ \\
\hline T7 & $50 \%$ RDF+50\% RR-N & $258 \mathrm{~cd}$ & $26.22 \mathrm{ab}$ & $239 \mathrm{~d}$ \\
\hline T8 & $75 \%$ RDF+25\% RR-N & $252 \mathrm{~d}$ & $24.38 \mathrm{~b}$ & $228 \mathrm{e}$ \\
\hline T9 & $50 \%$ RDF+50\% GM-N & $272 \mathrm{a}$ & $28.88 \mathrm{a}$ & $260 \mathrm{a}$ \\
\hline T10 & $75 \%$ RDF+25\% GM-N & $266 \mathrm{~b}$ & $26.21 \mathrm{~b}$ & $252 \mathrm{~b}$ \\
\hline T11 & Farmer practices (50:30:20) & $224 \mathrm{f}$ & $23.42 \mathrm{~b}$ & $246 \mathrm{c}$ \\
\hline & SEm \pm & 1.97 & 1.62 & 1.73 \\
\hline & CD (P=0.05) & 6.0 & 4.77 & 5.1 \\
\hline
\end{tabular}

FYM- farm yard manure, RR- rice residues, GM- green manure

Effect of long-term inorganic fertilizer and organic manure application on soil microbial biomass carbon

It was revealed that increase in application of inorganic fertilizers increased the microbial biomass carbon (Table no 4.3 ) in soil. Application of $50 \%$ and $100 \%$ RDF in rice significantly influenced the biomass Cover control. The 50\% RDF and 50\% FYM-N significantly increased the MBC than $100 \%$ RDF. The combination of inorganic fertilizer with organic manure at $50 \%$ and $75 \%$ recommended dose of fertilizer in rice showed significant increase in $\mathrm{MBC}$ over chemical fertilizer alone. The incorporation of green manure legumes and $\mathrm{N}$ fertilizer application significantly increased the microbial biomass and activities in rice-wheat system reported by Shah et al. (2010) ${ }^{[20]}$. For sustainable crop production and maintaining soil quality, input of organic manure like FYM is of major importance and should be advocated in the nutrient management of intensive cropping system for improving soil fertility and biological properties of soils concluded by Moharana et al. (2012) ${ }^{[15]}$. The effect was more pronounced at higher level of FYM and GM application and/or incorporation in soil. However, rice residues did not show any remarkable effect in the rice crop. The increase in $\mathrm{MBC}$ is the result of combination of inorganic and organic can be attributed to the readily available compound after 
decomposition of these organics supplying the required substrate to microbes for their multiplication.

Table 3: Effect of different combination of the inorganic fertilizer and organic manure on soil microbial biomass carbon after harvest of rice

\begin{tabular}{|c|c|c|}
\hline \multicolumn{2}{|c|}{ Treatments } & $\begin{array}{c}\text { Microbial biomass carbon } \\
\left(\mathbf{\mu g C g}^{-1}\right) \text { of dry soil }\end{array}$ \\
\hline T1 & Control & $135.28 \mathrm{f}$ \\
\hline T2 & $50 \%$ RDF $(40: 30: 20)$ & $165.12 \mathrm{e}$ \\
\hline T3 & $75 \%$ RDF & $207.71 \mathrm{~d}$ \\
\hline T4 & $100 \%$ RDF (80:60:40) & $237.40 \mathrm{c}$ \\
\hline T5 & $50 \%$ RDF+50\% FYM-N & $334.55 \mathrm{a}$ \\
\hline T6 & $75 \%$ RDF+25\% FYM-N & $283.20 \mathrm{~b}$ \\
\hline T7 & $50 \%$ RDF+50\% RR-N & $184.99 \mathrm{e}$ \\
\hline T8 & $75 \%$ RDF+25\% RR-N & $179.56 \mathrm{e}$ \\
\hline T9 & $50 \%$ RDF+50\% GM-N & $327.66 \mathrm{a}$ \\
\hline T10 & $75 \%$ RDF+25\% GM-N & $279.44 \mathrm{~b}$ \\
\hline T11 & Farmer practices (50:30:20) & $217.35 \mathrm{~cd}$ \\
\hline & SEm \pm & 7.42 \\
\hline & CD (P=0.05) & 21.90 \\
\hline
\end{tabular}

FYM- farm yard manure, RR- rice residues, GM- green manure

\section{Effect of different nutrient management practices on rice yield}

The yield of rice increased with increasing the levels of mineral nutrients from 50 to $100 \%$ RDF. Treatment $\mathrm{T}_{9}$ consisting of $50 \% \mathrm{RDF}+50 \% \mathrm{GM}-\mathrm{N}$ as received from green manuring registered highest grain yield $(70.23 \mathrm{q} / \mathrm{ha})$ of rice which was significantly superior to the control, farmer's practice and different levels of mineral nutrients i.e. from 50 to $100 \% \mathrm{RDF}$. It was because of the immobilization of nitrogen and comparable to that of $100 \%$ inorganic fertilizer treatment $\left(\mathrm{T}_{4}\right), 50 \%\left(\mathrm{~T}_{5}\right)$ and $75 \%\left(\mathrm{~T}_{6}\right) \mathrm{RDF}+25 / 50 \% \mathrm{~N}$ as received from FYM and $25 \% \mathrm{~N}$ received from $\mathrm{GM}$ in $\mathrm{T}_{10}$ respectively (Table 4). Significant residual effect of FYM and GM incorporation in soil was recorded on grain yield of rice. Thus, the use of FYM and GM with fertilizer $\mathrm{N}$ has helped in sustaining the yield of rice as reported by Singh et al (2001) ${ }^{[24]}$. Rice was found to be more responsive than rabi crops to green manuring, which might be due to direct effect of green manure in supplying nutrient to rice crop and beneficial effect on soil health as reported by Kumar and Singh (2010) ${ }^{[11]}$. Mehdi et al. (2011) ${ }^{[14]}$ studied the comparison of Sesbania and FYM applied at 20 ton $\mathrm{ha}^{-1}$ showed that Sesbania remained superior over the farm yard manure for improving the paddy and straw yield. The increased efficiency of NPK fertilizer with green manuring may be due to chemical, enzymatic and metabolic transformation of organic material, as the green manuring is continuously subject to degradation, thus more susceptible to change in metal uptake than inorganic soil fractions.

Table 4: Effect of long term inorganic fertilizer and organic manure application on rice yield

\begin{tabular}{|c|c|c|c|}
\hline \multicolumn{2}{|c|}{ Treatments } & \multicolumn{2}{c|}{ Yield q/ha } \\
\hline & & Grain & Straw \\
\hline T1 & Control & $13.13 \mathrm{e}$ & $23.29 \mathrm{e}$ \\
\hline T2 & $50 \%$ RDF (40:30:20) & $43.54 \mathrm{~cd}$ & $68.13 \mathrm{~cd}$ \\
\hline T3 & $75 \%$ RDF & $61.77 \mathrm{~b}$ & $92.08 \mathrm{a}$ \\
\hline T4 & $100 \%$ RDF (80:60:40) & $70.1 \mathrm{a}$ & $94.79 \mathrm{a}$ \\
\hline T5 & $50 \%$ RDF+50\% FYM-N & $69.27 \mathrm{a}$ & $93.13 \mathrm{a}$ \\
\hline T6 & $75 \%$ RDF+25\% FYM-N & $67.5 \mathrm{a}$ & $93.75 \mathrm{a}$ \\
\hline T7 & $50 \%$ RDF+50\% RR-N & $60.73 \mathrm{~b}$ & $81.46 \mathrm{~b}$ \\
\hline T8 & $75 \%$ RDF+25\% RR-N & $57.6 \mathrm{~b}$ & $77.5 \mathrm{~b}$ \\
\hline T9 & $50 \%$ RDF+50\% GM-N & $70.23 \mathrm{a}$ & $95.83 \mathrm{a}$ \\
\hline T10 & $75 \%$ RDF+25\% GM-N & $68.29 \mathrm{a}$ & $96.25 \mathrm{a}$ \\
\hline T11 & Farmer practices (50:30:20) & $51.04 \mathrm{c}$ & $76.46 \mathrm{~b}$ \\
\hline & SEm \pm & 2.78 & 3.72 \\
\hline & CD (P=0.05) & 8.15 & 10.90 \\
\hline
\end{tabular}

FYM- farm yard manure, RR- rice residues, GM- green manure

\section{Relationship of soil microbial biomass carbon with soil fertility and crop yield}

Correlation coefficient between the selected various component of soil fertility with soil microbial biomass carbon (MBC) was worked out and the values of correlation coefficient are presented in table 8. Correlation analysis was performed to quantify the relationship of soil MBC with soil fertility and crop yield. This analysis was carried out to find out the contribution of various component of soil fertility to soil MBC. The correlation study revealed that soil MBC was significantly and positively correlated with organic carbon, available nitrogen, phosphorous, potassium and crop yields. It can be concluded from the above results that the highly positive significant correlation coefficient was found between organic carbon, available nitrogen, phosphorous, potassium, and crop yield and it was explained by $\mathrm{r}=, 0.82,0.76,0.79$, $0.89,0.76$ and 0.74 , respectively during rice season. Zhong and Cai (2005) [33] reported that the most microbial parameters were mainly correlated with soil organic carbon content rather than $\mathrm{P}$ and $\mathrm{N}$ indicating that the application of $\mathrm{P}$ and $\mathrm{N}$ did not directly affect microbial parameters in the soil, but did so indirectly by increasing crop yields, thus promoting the accumulation of soil organic matter.

Table 5: Relationship between of soil fertility and crop yield with soil microbial biomass carbon (after 21 crop cycle)

\begin{tabular}{|l|l|}
\hline Parameters & R-value \\
\hline Microbial biomass carbon vs. organic carbon & $0.82^{* *}$ \\
\hline Microbial biomass carbon vs. available nitrogen & $0.76^{* *}$ \\
\hline Microbial biomass carbon vs. available phosphorous $0.79^{* *}$ \\
\hline Microbial biomass carbon vs. available potassium & $0.89^{* *}$ \\
\hline Microbial biomass carbon vs. grain yield & $0.76^{* *}$ \\
\hline Microbial biomass carbon vs. straw yield & $0.74^{* *}$ \\
\hline
\end{tabular}

FYM- farm yard manure, RR- rice residues, GM- green manure

\section{Reference}

1. Agarwal M, Nand R, Ram S. Long- term effect of inorganic and manure on physical and chemical properties of soil after 35 year of continuous cropping of rice-wheat. Pantnagar journal of Research. 2010; 8(1):7680 . 
2. Azam F, Farooq S, Lodhi A. Microbial biomass in agricultural soils-determination, synthesis, dynamics and role in plant nutrition. Pakistan J Biol. Sci. 2003; 6:629639.

3. Black CA. Method of soil analysis American Agronamy Inc., Madison, Wisconsin, USA, 1965, 131-137

4. Chen $\mathrm{CR}, \mathrm{Xu} \mathrm{ZH}$, Mathers NJ. Soil carbon pools in adjacent natural and plantation forests of subtropical Australia. Soil Sci. Soc. Am. J. 2004; 68:282-291.

5. El-Ghamry AM, Abid Subhani, El-Naggar EM. Effect of organic residues on soil microbial biomass in different Egyptian soils. Pakistan Journal of Biological Sciences. 2001; 4:1479-1483.

6. Fox CA, MacDonald KB. Challenges related to soil biodiversity research in agro ecosystems-issues within the context of scale of observation. Can. J Soil Sci. 2003; 83:231-244.

7. Gregorich EG, Liang BC, Drury CF, Mackenzie AF, McGill WB. Elucidation of the source and turnover of water soluble and microbial biomass carbon in agricultural soils. Soil Biol. Biochem. 2000; 32:581-587.

8. Jackson ML. Soil Chemical Analysis, prentice Hall of India Pvt. Ltd, New Delhi, 1967, 205.

9. Haney RL, Franzluebbers AJ, Hons FM, Hossner LR, Zuberer DA. Molar concentration of K2SO4 and soil pH effect estimation of extractable $\mathrm{C}$ with chloroform fumigation extraction. Soil Biol. Biochem. 2001; 33:1501-1507.

10. Hole DG, Perkins AJ, Wilson JD, Alexander IH, Grice $\mathrm{PV}$, Evans $\mathrm{AD}$ et al. Does organic farming benefit biodiversity? Biol. Conserv. 2005; 122:113-130.

11. Kumar V, Singh AP. Long -term effect of green manuring and FYM on yield and soil fertility status in rice- wheat cropping system. Science. 2010; 58(4):409412.

12. Krishna D. Studies on dynamic behaviour of phosphorous addition and its relationship with Rice (Oryza sativa L.) in a long term fertilizer experiment on a Mollisol. Thesis, Master of Science in Agriculture (Soil Science), G.B.P.U.A, 2003.

13. Mathers NJ, Mao XA, Xu ZH, Saffigna PG, BernersPrice SJ, Perera MCS. Recent advances in the application of C-13 and N-15 NMR spectroscopy to soil organic matter studies. Aust. J Soil Res. 2000; 38:769-787.

14. Mehdi SM, Muhammad S, Abbas ST, Ghulam S, Akhtar J. Integrated nutrient management for rice-wheat cropping system in a recently reclaimed soil. Soil Environ. 2011; 30(1):36-44.

15. Moharana PC, Sharma BM, Biswar DR. Long-term effect of nutrient management on soil fertility and soil organic carbon pools under a 6-year-old pearl milletwheat cropping system in an Inceptisol of subtropical India. Field Crops Research. 2012; 136:32-41.

16. Olsen SR, Cole CV, Franks SW, Dean LA. Estimation of available phosphorous in soils by extraction with sodium carbonate. U.S.D.A. Cir. No. 1954; 933:119.

17. Piper CS. Soil and plant analysis.Indian reprint. Hans Publications. Bombay, 1967.

18. Ros M, Hernández MT, Garci'a, C. Soil microbial activity after restoration of a semiarid soil by organic amendments. Soil Biol. Biochem, 2003; 35:463-469.

19. Sarathchandra SU, Ghani A, Yeates GW, Burch G, Cox NR. Effect of nitrogen and phosphate fertilisers on microbial and nematode diversity in pasture soils. Soil Biol. Biochem. 2001; 33:953-964.
20. Shah Z, Ahmd SR, Rahman HU. Soil microbial biomass and activities as influenced by green manure legumes and $\mathrm{n}$ fertilizer in rice-wheat system Pak. J Bot. 2010; 42(4):2589-2598.

21. Sharma JJ, Thakur RC, Saroch Kapil, Bharbava Manoj. Long- trem effect of integrated nutrient management supply in (Oryza sativa) - wheat (Triticum aestivum) on system productivity and soil health under irrigated condition. National symposium on resource conservation and agricultural productivity. 22-25, Lughiana, Punjab, 2004.

22. Sharma R, Dahiva S, Rathee A, Singh D, Nandal JK, Malik RK et al. Effect of INM on Growth, Yield, Economics and Soil Fertility in Rice-Wheat Cropping, 2009.

23. Sime T. Long term effect of fertilizer and manures on the availability and uptake of calcium, magnesium and sulphur by wheat in a Mollisol. Thesis, Master of Science in Agriculture (soil Science), GBPUA \& T, Pantnagar, 2001, 5-19.

24. Singh M, Singh VP, Reddy KS. Effect of integrated use of fertilizer nitrogen and FYM or Green manure on transformation of $\mathrm{N}, \mathrm{K}$ and $\mathrm{S}$ and Productivity of ricewheat system on a vertisol. Journal of the Indian Society of Soil Science. 2001; 49(3):430-435.

25. Subbiah V, Asija GL. A rapid procedure for estimation of available nitrogen in soil Current Science. 1956; 25:259260.

26. Swarup. A, Yaduvanshi, N.PS. Effect of integrated nutrient management on soil properties and yield of rice in Alkali Soil. J. Indian Soc. Soil sci. 2000; 48 (2): 279282. System. Indian Journal of Fertilisers. 5(3): 31-34

27. Tejada M, Herna'ndez MT, Garci'a C. Application of two organic amendments on soil restoration: effects on the soil biological properties. J Environ. ual. 2006; 35:1010- 1017.

28. Thakur R, Sawarkar D, Kauraw DL, Singh M. Effect of inorganic and organic sources on nutrients availability in a Vertisol. Agropedology. 2010; 20(1):53-59.

29. Vance ED, Brggke PC, Jenkin DS. An extraction method for measuring soil microbial biomass C. Soil Eiol. Biochem. 19(6):703-707.

30. Urkurkar JS, Tiwari A, Chitale S, Bajpai RK. Influence of Long- term Use of Inorganic and Organic Manures on Soil Fertility and Sustainable Productivity of Rice (oryza Sativa) and Wheat (triticum Aestivum) in Inceptisols. Indian Journal of Agricultural Sciences. 2010; 80(3):208212.

31. Walkley A. Black CA. Estimation of organic carbon by the chromic acid titration method. Soil Sci. 1934; 47:2938.

32. Yougun HE, Qingkui W, Silong W, Xiaojun Y. Characteristics of carbon and nitrogen of soil microbial biomass and their relationships with soil nutrients in Cunbnighamia lanceolata plantations. Front. For. China. 2007; 2(3):266-271.

33. Zhang Q, Wang G. Studies on nutrient uptake of rice and characteristics of soil microorganisms in a long-term fertilization experiments for irrigated rice. Journal of Zhejiang University Science. 2005; 6(2):147-154. 